\title{
Exploring the Linkage between Peripheral Vision and the Choice of Marketing Strategy
}

\author{
Pantri Heriyati
}

\begin{abstract}
Firm and industry are facing challenge from external environment and internally they have limited resource and capability. This condition may lead to firm's inflexibility in adopting marketing strategy. Therefore, to win competition firm should apply good strategy and master market knowledge. This study aims to assess firm peripheral vision capability and its impact to firm's decision over marketing strategy competitiveness. The peripheral typology consists of four quadrants: Vigilant, Neurotic, Focused and Vulnerable. The linkage of this typology and strategic decision will provide useful guide and important insight into firm's strategic behavior. Marketing strategy alternatives divided into two categorizations: customer acquisition and customer retention strategy. The finding of this study shows that in turbulence and stable environment, firm with high peripheral vision capability (Vigilant and Neurotic) will likely to adopt customer acquisition strategy and act aggressive in acquiring new customers. For firms with low peripheral vision capability (Focused and Vulnerable) they found to have indifference over adoption of customer acquisition retention strategy.
\end{abstract}

Index Terms-Customer acquisition strategy, customer retention strategy, marketing strategic alternatives peripheral vision capability.

\section{INTRODUCTION}

In this current situation, the pace of market change is accelerating. Some basic assumptions underlying this fact are: 1) the increase speed of product, service and idea imitation and substitution, 2) the life cycle of product is changing radically and much shorter in time, 3) competition is intensifying, 4) customers are more demanding and becoming less easier to convince through advertising and other promotion efforts, 5) the emerging of information technology. These situations require superb strategy based on firm's programs and action which is fit with the organizational structures, resources and current market requirements.

Former literatures suggest that firm should adopt a more relationship approach that centre in building long-term relationship with existing customer to achieve greater profitability [1]-[3] and to be considered as a paradigm shift in marketing [4]. On the contrary, literatures also emphasize that firm should aggressively seek new opportunity and create customer demand through innovation and product development before their rivals [5]. This problem exists due to lack of studies that explore the relevance of environment factors and firm internal capability to shape the competitive marketing strategy approach that lead to desirable firm

Manuscript received July 25; revised October 10, 2013.

Pantri Heriyati is with BINUS International, BINUS University, Senayan, Jakarta 10270, Indonesia (e-mail: pheriyati@binus.edu). performance. Accordingly, the fitness of marketing competitive strategy with external environment and the fitness with internal firm's capability are needed to be further explored.

Based on the above phenomena and literatures, this research develops several arguments, first, to investigate the relationship of firm's position in the typology of peripheral vision with marketing strategy choice, specifically, customer acquisition versus customer retention strategy. Second, if peripheral vision will benefit firm in competitive marketing strategy then it needs to investigate how it would relate to customer acquisition versus customer retention strategy.

\section{Literature REVIEW PROCEDURE FOR PAPER SUBMISSION}

Resource-Based View underlying the peripheral vision capability as firm's specific capability in generating knowledge about the market and customer. Theory of Exchange is proposed in explaining the concept of Relational Exchange and Relationship Marketing as the basic trade-off between firms choosing a customer acquisition or customer retention as its competitive strategy.

\section{A. Peripheral Vision}

\begin{tabular}{|c|c|c|}
\hline & Internal Peripheral & sion capability \\
\hline & Low & High \\
\hline External & $\begin{array}{l}\text { I V } \\
\text { Vulnerable firms operate in a } \\
\text { relativaly high turbulence market, } \\
\text { lacking of peripheral vision to } \\
\text { purus their strategy that demands } \\
\text { strong capacity for acanning the } \\
\text { edges of the businass. }\end{array}$ & $\begin{array}{l}\text { I } \\
\text { Vigilant firm: firm with } \\
\text { highly developed peripheral } \\
\text { vision capability to match with } \\
\text { a relative high turbulence } \\
\text { market. }\end{array}$ \\
\hline turbulence & 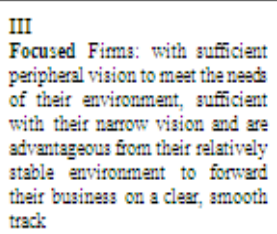 & $\begin{array}{l}\text { II } \\
\text { Neurotic firms that are } \\
\text { developing peripheral vision } \\
\text { capability more than it need, } \\
\text { leading to a nerotic } \\
\text { organization that suffers from } \\
\text { exhaustivensas of resource and } \\
\text { information overlosd. }\end{array}$ \\
\hline
\end{tabular}

Fig. 1. Firm typology.

The operational definition on peripheral area and peripheral vision are also developed in this research as a result of Focus Group Discussion (FGD) which involving panel both practitioners and academician. From FGD, peripheral area is referred as firm's current or potential business environment which has larger and sometimes indefinite coverage in term of customer, competitor and other market forces, more global orientation and thus often contains uncertainty. This capability enables firm to foresee 
the opportunity and threats contained in its peripheral area, so that it is able to take necessary strategy and action to fill up the opportunity or to anticipate its environmental threats.

Ref. [6] has conceptualized model of process in developing firm's peripheral vision capability, as shown in Fig. 1.

\section{B. Relational Exchange}

The Nordic School of Services [7], [8] and the Social Exchange School [9], [10] were among the first to analyze exchange relationships. The customer capability to evaluate those benefits will convert to a closer relationship or to change supplier. Every industry is characterized by its own bandwidth of transactional and relational exchanges [11]. Customer satisfaction is likely to be effective for short-term customer, whereas marketing that focused on building trust and commitment is more effective for maintaining the long-term group of customer[12], [13].

\section{Customer Acquisition Strategy}

The marketing literature emphasizes strategies designed to obtain additional customers, encourage brand switching to own brand and increase purchase frequency [14]. These are considered as the objective of acquisition marketing strategy [15].

\section{Customer Retention Strategy}

Since the past decade, marketer and practitioner increasingly put their attention and effort on managing current or existing customer as critical source of customer value [16], [17]. Defensive marketing strategy is the body of knowledge that uses customer as a shield in their battled with rival in a specific market [1], [18]. The focus is essentially on competition and the concern is mostly to customer in the sense to reduce customer turnover or patronage switching [15].

\section{RESEARCH MODEL AND HYPOTHESES}

The model in general depicts blocks which purports relationship between peripheral vision typology and marketing strategic choice namely customer acquisition strategy and customer retention strategy. The simple research model as Fig. 2 shows.

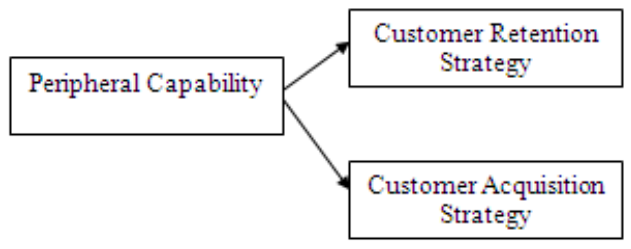

Fig. 2. Research model.

\section{A. Research Hypotheses}

1) Relationship of firm's typology and marketing strategy choice

H1a: In turbulent environment, firm with high internal capability (Vigilant) is likely to adopt a customer acquisition strategy.

H1b: In stable environment, firm with high peripheral vision capability (Neurotic) is likely to adopt a customer acquisition strategy
H1c: Firm with high peripheral vision capability, inturbulent environment (Vigilant) will be likely to adopt customer acquisition strategy than firm in a stable environment (Neurotic).

H2a: Firm in stable environment, with low peripheral vision capability (Focused) will be likely to adopt customer retention strategy

$\mathrm{H} 2 \mathrm{~b}$. Firm in turbulent environment with low peripheral vision capability (Vulnerable) is likely to adopt customer retention strategy.

H2c: Firm with low peripheral vision capability, in stable environment (Focused) will be likely to adopt customer retention strategy than firm in turbulent environment (Vulnerable).

\section{RESEARCH METHODOLOGY}

\section{A. Variable and Construct Measurement}

The independent variable peripheral vision typology is developed under the matrix of firm's strength and capability of peripheral vision and environment factors. Firm's internal peripheral capability is measured by four dimensions namely Leadership Orientation; Strategy Making Knowledge Management System and Configuration (Structure and Incentive) and Environment Factors measured by the nature of market strategy; Environment Complexity; and Environment Volatility. The dependent variable Customer Acquisition Strategy is measured: Firm's Product development effort; New/modified product launched; Customer attraction program, and Competitor orientation. While, Customer Retention Strategy is measured by: Personal Communication; Firm-customer's Trust Development; Firm-customer's Bonding Development; Customer Complaint Management; and Switching Barriers.

\section{B. Final Stage Data Analysis and Research Finding}

The main field survey took place from February to May 2009, where a total of 150 qualified responses were returned out of 300 sets of distributed questionnaire. Unit analysis is company (CMO). Typology re-code is used in classifying firms into one of four typologies and applying simple mean calculation. After re-coding, the frequencies of firms will be computed to identify member of each typology.

Accounted for $51 \%$ ( 77 samples) of respondents are food and beverage industry. Followed by pharmacy and automotive industry (16\% and $17 \%)$, cosmetics ( $8 \%)$ and the rest are from home appliances, electronics and other industry $(6 \%, 5 \%, 9 \%)$. Most of respondents $(57 \%)$ stated that they are serving national markets for their product and brand. For major cities and overseas markets each accounted for $15 \%$ of total (22 and 23 respondents). Only a small number of respondents have served Java and Jakarta area (4\% and 9\%). From the statistical analysis, the member of each quadrant of peripheral typology is shown in Table I below:

TABLE I: TYPOLOGY FREQUENCY

\begin{tabular}{|l|l|l|}
\hline Typology & Frequency & Percent \\
\hline Vigilant & 57 & 38 \\
Neurotic & 21 & 14 \\
Focus & 47 & 31.3 \\
Vulnerable & 25 & 16.7 \\
& & 100 \\
Total & 150 & \multicolumn{2}{l}{} \\
\hline
\end{tabular}

Source: primary date 
Sign Test analysis is conducted to test the hypotheses. The following Table II presents the summary of the statistical finding regarding the tests and methodology used.

TABLE II: SUMMARY OF HYPOTHESES TESTING

\begin{tabular}{|c|c|c|c|c|c|}
\hline$T$ & Hla. & $\begin{array}{l}\text { In turbulance enviromment, firm with high } \\
\text { internal capability (Vigilart) is likely to } \\
\text { adopt a customer acquisition strategy } \\
\text { (CAS). }\end{array}$ & \begin{tabular}{|l|} 
Sign test \\
$\mathrm{Z}$ value -4.819
\end{tabular} & $\begin{array}{l}\text { Sig } \\
2 \text { tailed: } \\
0.000 / 2\end{array}$ & Accepted \\
\hline 2 & HIb & $\begin{array}{l}\text { In stabla environment, firm with high } \\
\text { internal capability (Neurotic) is likely to } \\
\text { adopt a customer acquisition strategy } \\
\text { (CAS) }\end{array}$ & \begin{tabular}{|l|} 
Sign test \\
Z value -2.729
\end{tabular} & $\begin{array}{l}\text { Sig } \\
2 \text { tailed: } \\
0.006 / 2\end{array}$ & Accepted \\
\hline 3 & HIC & $\begin{array}{l}\text { Therefore, Vigilant will be likaly to ad opt } \\
\text { CAS than Neurotic }\end{array}$ & $\begin{array}{l}\text { Valua of } \\
\text { contrast } \\
0.1970\end{array}$ & \begin{tabular}{|l} 
Not sig 0.115 \\
\end{tabular} & Rejected \\
\hline 4 & $\mathrm{H} 2 \mathrm{a}$ & $\begin{array}{l}\text { Firm in stable anvironment, with low } \\
\text { internal capability (Focused) will be likely } \\
\text { to adopt a customer retention strategy } \\
\text { (CRS). }\end{array}$ & $\begin{array}{l}\text { Sign test: } \\
\text { Zvalue- } \\
3.529\end{array}$ & $\begin{array}{l}\text { Sig } \\
2 \text { tailed: } \\
0.000 / 2\end{array}$ & \begin{tabular}{|l} 
Rejected \\
\end{tabular} \\
\hline 5 & $\mathrm{H} 2 \mathrm{~b}$ & $\begin{array}{l}\text { Firm in turbulance environment with low } \\
\text { internal capability (Vunerable) is likely to } \\
\text { adopt customer retention strategy (CRS). }\end{array}$ & \begin{tabular}{|l|} 
Sign test: \\
Z value -2.005
\end{tabular} & \begin{tabular}{|l|} 
Sig \\
2 tailed: \\
$0.045 / 2$
\end{tabular} & Rejected \\
\hline 6 & H2c & $\begin{array}{l}\text { Focused fim will be likely to adopt CRS } \\
\text { than Vulnerable. }\end{array}$ & \begin{tabular}{|l|} 
Value of \\
contrast \\
-0.3273 \\
\end{tabular} & Not sig 0.023 & Rajected \\
\hline
\end{tabular}

\section{DISCUSSION}

\section{A. The Relationship of Vigilant and Neurotic Firms with Customer Acquisition Strategy}

Hypothesis 1A has predicted that firm in a relative turbulent environment and relative high peripheral vision capability (vigilant) will likely adopt a customer acquisition strategy than customer retention strategy.

Based on the statistical analysis this prediction is accepted. As studied by [19], the choice of marketing competitive strategy is related to manager perceptions of the product/market environment aspects and the organization context. Customer acquisition strategy attempt at attracting new customer is mostly suitable for growth market which characterized easier for firm to expand. This market offers companies to grow at least as fast as the market grow [19]. This argument is supported by the data that most of the firms in vigilant typology are in growth stage of its product life cycle. Hypothesis 1B predicts that firm in a relative stable environment with relative high peripheral vision capability (Neurotic firm) will be likely to adopt customer acquisition strategy. In a stable market with mature product, market has fewer opportunities for firm to grow. In this typology, the majority of the respondents are in the maturity stage of product life cycle. A customer acquisition strategy which attempt to develop new customer is applicable in this market by exploiting competitor's weaknesses and then making an attack [19].

Hypothesis 1A and IB leads to hypothesis 1C which predicts vigilant firms will be more likely to adopt Customer Acquisition Strategy than Neurotic. Statistical analysis has rejected this hypothesis. For Neurotic, relative stable market is considered less attractive than in growth market. Therefore it is an increases motivation to look for opportunity and find possibility for market growth. This motivation leads to over-scanning behavior.

\section{B. The Relationship of Focused and Vulnerable Firms with Customer Retention Strategy}

Hypothesis 2A is rejected. In retention strategy, firms use customer as a shield in their battled with rival in a specific market [1], [15], [20], [21]. Theoretically, in non-growth market firm should be able to attract competitors' dissatisfied customers; there are always dissatisfied customers that will consider switching to other brand. Brand advertising then designed to attract the customer dissatisfied [15], [18]. In this research, Focused firm are operating in industry with a relative stable market with mature stage of product life cycle.

Hypothesis 2B was concluded to be rejected. In practical perspective Focused firm has market that is characterized as fragmented and firms often take market consolidation to crack all possible opportunity from the market while strengthening its position [22]. In mature market, the various brands become more similar, therefore firms attempt to differentiate the product. This sometime follows with an increase in price deals [23]. For Vulnerable firms, in spite of their lack of market knowledge, the attractiveness of the market and the opportunity that the market offer for growth has lead them to locate a market where they can be confident to serve. They tend to be new players in the market and are identified as market nicher [24]. Both Focused and Vulnerable typology have shown no significant different in their likeliness to adopt customer acquisition or customer retention strategy, which concluded why Hypotheses $2 \mathrm{C}$ is rejected.

\section{CONCLUSION}

Based on the above discussion, we may draw conclusion as below.

1) This research shows that the factor that influence relationship of firm and marketing strategy is the firm's internal capability (peripheral vision capability) — not environment factor.

2) Concurrently, firms with high peripheral vision capability tend to adopt customer acquisition strategy and act aggressively. Where, firm with low peripheral vision capability is likely to adopt both customer acquisition strategy customer retention strategies.

3) This research has contributed in marketing theory by developing new construct to measure customer acquisition and retention strategy.

\section{LIMITATION AND FURTHER RESEARCH}

\section{A. Limitation}

In adapting the concept used in peripheral vision typology [6], through the factor analysis process had found factors with poor validity level. Past literatures also noted that in typology frameworks have showed little evidence of content and predictive validity exist [25]. In addition this problem may due to highly subjectivity of respondents' perception over their environment and internal firm capacity which created bias in the typology formation Therefore, [26] made a recommendation that research in typology or other firms classification framework should more concern with the utilization of the framework rather than validation issue.

This research has not provide systematic explanation on how firms make a shift from one typology to another, how often such shift are made, timing and the transitional point of the shift and the implication to firms' performance. 


\section{B. Further Research}

Further research should address the characteristic of the strategic group member of typology; the stability or the dynamic of each group. Specifically to explain the phenomena that might occur whether there are changes in groups' typology, and if the changes occur, whether it occurs over period of time. What are factors that might influence the changes and is it tied to industry evolution and or to firm's internal process? In addition, a longitudinal research design may be needed to better understand the nature of changes in firm typology and to identify the nature of firm's adaptive cycle. Further research to capture the firm's adaptive cycle will include the understanding of the evolution of the strategic group in each typology, shift in strategic type and the role of industry and managerial role variables (Zahra, 1985).

\section{REFERENCES}

[1] J. D. Michael and F. Selnes, "Customer portfolio management: toward a dynamic theory of exchange relationship," Journal of Marketing, vol. 66, pp. 1-17, Fall 2004.

[2] V. Rajkumar and V. Kumar, "A customer lifetime value framework for customer selection and resources allocation strategy," Journal of Marketing, vol. 68, pp. 106-125, October 2004.

[3] G. Day, "Managing market relationship," Journal of Academy of Marketing Science, pp. 24-30, 2004.

[4] J. H. Sheth and A. Parvatiyar, "The evolution of relationship marketing," International Business Review, vol. 4, no. 4, pp. 397-419, 1995.

[5] W. J. Keegan and H. Davidson, Offensive Marketing, Elsevier, UK: Butterworth-Heinemann, 2003.

[6] G. S. Day and P. J. H. Schoemaker, Peripheral vision: Detecting the Weak Signals that Will Make or Break Your Company, Boston: Harvard Business School Press, 2006.

[7] L. L. Berry, "Relationship marketing," in Exchange Relationship in Consumer Market? European Journal of Marketing, P. Jaqueline, Ed. Nov. 1997, vol. 33, pp. 19-37.

[8] C. Gronroos and E. Gummesson, "Service marketing-nordic school perspective," in Exchange Relationship in Consumer Market? European Journal of Marketing, P. Jaqueline, Ed. Vol. 33, pp. 19-37, Nov. 1997.

[9] R. P. Bagozzi, "Marketing as exchange," Journal of Marketing, vol. 39, pp. 32-39, 1975.

[10] S. D. Hunt, "General theories and the fundamental explanation of marketing," Journal of Marketing, vol. 447, pp. 9-17, 1983.

[11] W. Reinartz and V. Kumar "The impact of customer relationship characteristics on profitable lifetime duration," Journal of Marketing, vol. 67, pp. 77-99, 2003

[12] R. M. Morgan and S. D. Hunt, "The Commitment-Trust theory of relationship marketing," Journal of Marketing, vol. 58, pp. 20-38, July 1994.

[13] E. Garbarino and M. S. Johnson, "The different roles of satisfaction, trust, and commitment in customer relationship," Journal of Marketing, vol. 63, pp. 70-78, 1999.
[14] D. E. Boyd, "Defensive marketing's use of post-purchase telecommunications to create competitive advantages: A strategic analysis," The Journal of Consumer Marketing, vol. 13, pp. 26-34, 1996.

[15] C. Fornell and B. Wernerfelt, "A model for customer complaint management," Marketing Science, pp. 287-298, 1988.

[16] R. N. Bolton, K. Lemon, and P. C. Verhoef, "The theoritical underpinnings of customer asset management: A framework and propositions for future research," Journal of the Academy of Marketing Science, vol. 32, no. 3, pp. 271-292, 2004.

[17] E. Gummesson, Total Relationship Marketing, $2^{\text {nd }}$ ed. UK: Butterworth-Heinemann, 2002.

[18] C. Fornell and B. Wenerfelt, "Defensive marketing strategy by customer complaint management: A theoretical analysis," Journal of Marketing Research, vol. 24, pp. 337-463, Nov. 1987.

[19] M. C. Burke, "Strategic choice and marketing managers: An examination of business-level marketing objectives," Journal of Marketing Research, pp. 345-359, Nov. 1984.

[20] C. Fornell and R. A. Westbrook, "The vicious circle of consumer complaint," Journal of Marketing, vol. 84, pp. 68-78, 1984.

[21] C. Fornell, "A national customer satisfaction barometer: The Swedish experience," Journal of Marketing, vol. 56, pp. 6-21, Nov. 1992.

[22] P. Kotler, Marketing Management, $11^{\text {th }}$ ed., New Jersey: Prentice Hall 2003.

[23] D. W. Cravens and N. F. Piercy, Strategic Marketing, $7^{\text {th }}$ Ed, NY: MacGraw Hill, 2003.

[24] J. Mullin, O. C. Walker, and H. W. Boyd Jr, Marketing Management: A Strategic Decision-Making, McGraw-Hill/Irwin, 2008.

[25] S. A. Zahra, "Typology of strategic orientation: review, critique and future directions," Southern Management Proceeding, Research on the Miles-Snow, pp. 56-60, 1985.

[26] R. Speed, "Maximizing the potential of strategic typologies for marketing strategy research," Journal of Strategic Marketing, vol. 1, pp. 171-188, July 1993.

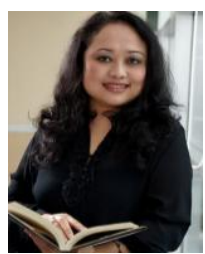

Pantri Heriyati was born in Jakarta, Indonesia on July 1. She got the bachelor degree in economics from Padjadjaran University Bandung, Indonesia in 1995; master degree in marketing at Wollongong, Australia in 1997; Ph.D. in marketing management was earned from University of Indonesia in 2009.

She currently works as the head of school-management at BINUS International, BINUS University-Jakarta, the biggest and highly reputable private education institution in Indonesia. She also has a strong industrial background with more than ten years of experience in multinational companies. Her research interest is in corporate marketing strategy and consumer behavior. Among her publication are: The Influence of Employee Satisfaction on Supporting Employee Performance and Retention, Moderated by Employee Engagement, International Journal of Economics and Management, vol. 6 , no. 1, April 2012; The Effect of Word Of Mouth Communication and Perceived Quality on Consumer Decision Making of BlackBerry Smartphones' Contemporary Management Research Pages 329-336, vol. 7 , no. 4, December 2011

To keep her updated in marketing knowledge, Dr. Heriyati joined AMA membership from year 2010. She is also listed in numbers of national journal referee committee. 